\title{
Poorly Differentiated Hepatocellular
}

\section{Carcinoma}

National Cancer Institute

\section{Source}

National Cancer Institute. Poorly Differentiated Hepatocellular Carcinoma. NCI

Thesaurus. Code $C 96791$.

A hepatocellular carcinoma characterized by the presence of malignant pleomorphic cells forming solid patterns. 